\title{
DIALEKTIKA PERLINDUNGAN HUKUM BAGI GURU DALAM MENDISIPLINKAN SISWA DI SEKOLAH
}

\author{
Istiqomah ${ }^{1}$, Fokky Fuad ${ }^{1}$ Suparji Achmad ${ }^{1}$ \\ ${ }^{1}$ Universitas Al-Azhar Indonesia, \\ Masjid Agung Al-Azhar, Jl. Sisingamangaraja No.2, RT.2/RW.1, Selong, Kec. Kby. Baru, Kota Jakarta \\ Selatan, Daerah Khusus Ibukota Jakarta 12110 \\ *Istiqomah933@gmail.com
}

\begin{abstract}
Teachers as educators are often in a dilemmatic position, between the demands of the profession and community treatment. Teachers are required to be able to deliver students to achieve educational goals. However, when teachers try to punish students in order to enforce discipline. spontaneously parents and society categorize it as an act that violates human rights and child protection laws. The formulation of the problem in this study are: First, how to protect the rights of teachers in disciplining students? Second, Has the Court Decision related to the teacher's efforts to discipline students provided protection for teachers or vice versa? The research method used is to use the normative legal method. The theoretical framework used is to use the theory of legal protection developed by Satjipto Rahardjo. The conclusions generated in this study: First, in the context of the dialectics between norms that meet each other, a legal synthesis appears through the presence of the Supreme Court's Decision which is able to provide protection for teachers. Second, that the Supreme Court Decree No. 1554 K / PID / 2013 has been able to provide optimal protection for teachers to carry out their functions as educators.
\end{abstract}

\section{KEYWORDS Dialectics, Teacher Protection, Student Discipline}

\section{INTRODUCTION}

Undang-Undang Sistem Pendidikan Nasional No. 20 tahun 2003 menyebutkan Pendidikan adalah usaha sadar dan terencana untuk mewujudkan suasana belajar dan proses pembelajaran agar peserta didik secara aktif mengembangkan potensi dirinya untuk memiliki kekuatan spiritual keagamaan, pengendalian diri, kepribadian, kecerdasan, akhlak mulia, serta keterampilan yang diperlukan dirinya, masyarakat, bangsa dan negara. (Hanafy, 2014; Tampubolon, 2013)

Pendidikan nasional berfungsi mengembangkan kemampuan dan membentuk watak serta peradaban bangsa yang bermartabat dalam rangka mencerdaskan kehidupan bangsa yang bertujuan untuk mengembangkan potensi peserta didik agar menjadi manusia yang beriman dan bertakwa kepada Tuhan Yang Maha Esa, berakhlak mulia, sehat, berilmu, cakap, kreatif, mandiri, dan menjadi warga negara yang demokratis serta bertanggung jawab.(Citra, 2012; Mulyani, 2011; Susanti, 2011) 
Penelitian tentang perlindungan bagi guru dalam mendisiplinkan siswa menjadi penting disebabkan oleh beberapa hal:(Fachrian, 2020; Haikal, 2017; Panjaitan \& Mahzaniar, 2019; Sudibyo \& Kiyamudin, 2019)

Pertama, bahwa sebagai tenaga pendidik guru seringkali berada pada posisi yang dilematis, antara tuntutan profesi dan perlakukan masyarakat. Guru dituntut untuk mampu menghantarkan peserta didik mencapai tujuan pendidikan. Namun ketika guru berupaya untuk melakukan hukuman terhadap peserta didik dalam rangka menegakkan kedisiplinan. maka secara spontan orang tua dan masyarakat mengkategorikannya sebagai tindakan melanggar Hak Asasi Manusia dan undang-undang perlindungan anak. Dengan kekuatan tersebut eksistensi guru berada pada posisi sangat pasif dan lemah.(Gandara, 2018; Nurmala, 2018)

Kedua, bahwa dalam upaya meningkatkan disiplin dan potensi siswa, guru sering kali menerapkan hukuman kepada siswa yang justru menjeratnya kedalam kasus hukum. Banyaknya kasus guru yang terjerat kasus hukum dalam upaya meningkatkan disiplin dan potensi siswa, membuat guru bersifat apatis. Guru menjadi takut untuk bertindak apabila melihat indisipliner yang dilakukan oleh siswa. (Komara, 2016; Matnuh, 2017; Muchith, 2016; Suprihatin, 2015)

Mereka beranggapan bahwa siswa itu bukan anak kandungnya sehingga tidak perlu repot - repot untuk mendidiknya. Apabila anak tersebut dihukum, maka guru akan masuk penjara. Inilah pemikiran yang berkembang di antara guru. Apabila kondisi ini dibiarkan, maka bisa dibayangkan bagaimana moral peserta didik kita nantinya.

Kerangka Teoritik yang digunakan dalam penelitian ini adalah mengacu kepada Teori Perlindungan Hukum yang diungkap oleh Satjipto Rahardjo. Perlindungan hukum menurutnya adalah memberikan pengayoman terhadap hak asasi manusia (HAM) yang dirugikan orang lain dan perlindungan itu di berikan kepada masyarakat agar dapat menikmati semua hak-hak yang diberikan oleh hukum. Hukum dapat difungsikan untuk mewujudkan perlindungan yang sifatnya tidak sekedar adaptif dan fleksibel, melainkan juga prediktif dan antisipatif. Hukum dibutuhkan untuk mereka yang lemah dan belum kuat secara sosial, ekonomi dan politik untuk memperoleh keadilan sosial (Rahardjo, 2000: 54). Dalam kaitan dengan perlindungan guru, maka hukum harus diupayakan untuk mempu memberikan perlindungan hukum secara optimal kepada guru dalam menjalan fungsinya mendidik siswa. Hukum dilihat dari kemampuannya secara prediktif dan antisipatif dalam memberikan layanan hukum bagi guru guna mendukung sebuah sistem belajar.

Berdasarkan hal tersebut di atas, maka rumusan yang diungkap dalam penelitian ini antara lain: Pertama, Bagaimanakah melindungi hak guru dalam mendisiplinkan siswa? Kadua, Apakah Putusan Pengadilan yang berkaitan dengan upaya guru mendisiplinkan siswa telah memberikan perlindungan bagi guru ataukah sebaliknya? Tujuan yang diharapkan dalam penelitian ini antara lain adalah: pertama, untuk menganalisis bagaimanakah upaya perlindungan hak bagi guru dalam upaya melindungi siswa. Kedua, menganalisis bagaimana dialektika antara perlindungan hak guru dan hak siswa dalam sebuah system pendidikan. 


\section{METHODOLOGY}

Metode penelitian yang digunakan dalam penelitian ini adalah menggunakan metode penelitian hukum normative. (Diantha, 2016) Dalam hal ini peneliti akan melakukan kajian berdasarkan studi kasus yang terdapat dalam putusan undang-undang yang telah berkekuatan hukum tetap. (Soekanto \& Mamudji, 2001) Terdapat dua kasus yang dibahas dan kedua kasus tersebut memiliki sudut pandang yang berbeda terhadap hukum poendidikan yang bekerja. (Mukti Fajar \& Achmad, 2010)Bahan hukum yang digunakan dalam penelitian ini adalah UU No.14 Tahun 2005 tentang Guru dan Dosen dan Paraturan Pemerintah Nomor 74 Tahun 2008 tentang Guru sebagai bahan hukum primer penelitan. bahan hukum sekunder yang digunakan dalam penelitian ini adalah mengacu kepada UU No.35 Tahun 2014 tentang Perlindungan Anak. (Nurmala, 2018)

\section{RESULTS AND DISCUSSION}

\section{Perlindungan bagi Guru dalam Mendisiplinkan Siswa sebuah Dialektika}

Secara etimologis "disiplin" berasal dari bahasa Latin yakni, desclipina yang menunjukkan kepada kegiatan belajar mengajar. Sedangkan dalam bahasa Inggris kata disiplin disebut discipline, yang berarti tertib, taat, atau mengendalikan tingkah laku, penguasaan diri, kendali diri.(Amri, 2013) Disiplin adalah sikap mental yang tercermin dalam perbuatan atau tingkah laku perorangan, kelompok atau masyarakat berupa kepatuhan atau ketaatan (obedience) terhadap peraturanperaturan dan ketentuan yang berlaku dalam masyarakat untuk tujuan tertentu.(Sinungan, 2018)

Disiplin sangat perlu ditanamkan dalam kehidupan siswa, karena begitu banyak tujuan disiplin. Berikut ini beberapa hal tujuan disiplin yaitu: Memberi dukungan bagi terciptanya perilaku yang tidak menyimpang, mendorong siswa untuk melakukan perbuatan yang baik dan benar, Membantu siswa memahami dan menyesuaikan diri dengan tuntutan lingkungannya serta menjauhi hal-hal yang dilarang sekolah. Siswa belajar hidup dengan kebiasaan-kebiasaan yang baik dan bermanfaat baginya serta lingkungannya. Disiplin sangat perlu dimiliki oleh setiap individu termasuk siswa di sekolah. Banyak manfaat yang akan kita rasakan apabila kita memiliki sifat disiplin. Berikut ini adalah beberapa ciri-ciri siswa yang dikatakan disiplin yaitu: kehadiran yang baik, pemberitahuan bila tidak hadir yang dibenarkan, ketepatan waktu, sopan santun dan kesusilaan (Sutisna, 1983).

Disiplin sangat berpengaruh dalam perkembangan kode moral, meskipun anak memerlukan disiplin, disiplin merupakan masalah yang serius bagi anak yang lebih besar(Hurlock, 2001). Disiplin sangat penting bagi peserta didik, maka dari itu perlu disiplin ditanamkan secara konsisten kepada siswa. Dengan menanamkan perilaku disiplin secara konsisten akan menjadi suatu kebiasaan yang tertanam dalam diri siswa. Mungkin tidak asing bagi kita orang-orang sukses pada umunya karena memiliki sifat disiplin dalam dirinya. Orang-orang yang berhasil dalam bidangnya masing-masing umumnya mempunyai kedisiplinan yang tinggi. Sebaliknya orang yang gagal, umumnya tidak disiplin (Imron, 2011).

Disiplin dapat membantu seorang siswa tumbuh dengan kepercayaan dan kontrol diri yang baik, yang dituntut oleh kesadaran yang baik dari dirinya dan hidupnya serta perasaan yang baik tentang dirinya dan perasaan tanggung jawab serta kepeduliannya terhadap lingkungannya. Inti dari disiplin adalah untuk mengajar atau seseorang yang mengikuti ajaran dari seorang pemimpin. Tujuan dekat dari arti disiplin adalah untuk membuat anak/siswa terlatih, terkontrol, dengan mengajarkan mereka bentukbentuk tingkah laku 
yang pantas dan yang tidak pantas atau yang masih asing bagi mereka. Tujuan jangka panjang dari disiplin ialah perkembangan dari pengendalian diri sendiri yaitu dalam hal mana anak/peserta didik dapat mengarahkan diri sendiri tanpa pengaruh dari luar.

Pengendalian berarti menguasai tingkah laku sendiri dengan berpedoman pada norma-norma yang jelas, standar-standar dan aturan-aturan yang sudah menjadi milik diri sendiri. Karena itu baik orang tua maupun guru haruslah secara terus menerus berusaha untuk makin memainkan peranan yang makin kecil dari pekerjaan pendisiplinan itu, dengan secara bertahap mengembangkan pengendalian diri sendiri dan pengarahan diri sendiri pada anak/siswa. Menanamkan disiplin adalah proses mengajar bagi diri guru atau orang tua dan suatu proses belajar bagi anak/siswa (Aulina, 2013)

Dalam proses pembelajaran di kelas mungkin saja terjadi kekerasan dalam bentuk hukuman dari seorang guru kepada seorang siswa. Misalnya; siswa yang tidak menuruti aturan sekolah; seperti; melanggar tata tertib sekolah, tidak mengerjakan Pekerjaan Rumah (PR). Sehingga si guru merasa tidak dihargai dan dihormati, maka terjadilah hukuman fisik dari guru kepada siswa dalam bentuk tamparan, pukulan, jeweran dan lain sebagainya. Hukuman dimaksud pada dasarnya adalah hukuman yang mendidik, agar si anak tidak melanggar aturan yang telah ditetapkan di sekolah. Akan tetapi dalam melakukan hukuman fisik ini oleh guru dihadapkan kepada Undang-Undang Nomor 23 Tahun 2002 tentang Perlindungan Anak, yang memberikan hak anak untuk diperlakukan dan dilindungi agar dapat hidup, tumbuh dan berkembang dan berpartisipasi secara optimal sesuai dengan harkat dan martabat kemanusiaan, serta mendapat perlindungan dari kekerasan dan diskriminasi sesuai yang tertera dalam Pasal 1 Undang-Undang Nomor 23 Tahun 2002. Kalau demikian halnya guru tidak akan dapat menghukum siswa yang melanggar aturan sekolah. Padahal setiap siswa tidak akan memiliki kemampuan yang sama, karena terdiri dari beberapa keluarga dengan lingkungan yang berbeda. Kemudian sebagian siswa sebagai manusia terkadang lebih menonjol sifat hewaninya ketimbang sifat kemanusiaannya, sehingga harus melalui pemukulan secara fisik baru timbul kesadarannya sebagai manusia.

Dalam hal ini guru menghadapi dilema untuk menegakkan disiplin melalui pendidikan yang ia jalankan. Pada satu sisi ia dilindungi oleh Undang-undang Guru dan Dosen khususnya perlindungan yang diberikan oleh peraturan Pemerintah No.74 Tahun 2008 tentang Guru. Undang-undang No. 14 Tahun 2005 tentang Guru dan Dosen dalam pasal 39 tegas menyatakan:

a. Pemerintah, pemerintah daerah, masyarakat, organisasi profesi, dan/atau satuan pendidikan wajib memberikan perlindungan terhadap guru dalam pelaksanaan tugas.

b. Perlindungan sebagaimana dimaksud pada ayat (1) meliputi perlindungan hukum, perlindungan profesi, serta perlindungan keselamatan dan kesehatan kerja.

c. Perlindungan hukum sebagaimana dimaksud pada ayat (2) mencakup perlindungan hukum terhadap tindak kekerasan, ancaman, perlakuan diskriminatif, intimidasi, atau perlakuan tidak adil dari pihak peserta didik, orang tua peserta didik, masyarakat, birokrasi, atau pihak lain.

Pada sisi yang lain terdapat perlindungan terhadap anak, tentunya siswa sekolah adalah termasuk anak dalam kaitan ini. Menurut Maidin Gultom, perlindungan anak adalah segala usaha yang dilakukan untuk menciptakan kondisi agar setiap anak dapat 
melaksanakan hak dan kewajibannya demi perkembangan dan pertumbuhan anak secara wajar baik fisik mental dan sosial. Perlindungan anak merupakan perwujudan adanya keadilan dalam suatu masyarakat, dengan demikian perlindungan anak diusahakan dalam berbagai bidang kehidupan bernegara dan bermasyarakat. Kegiatan perlindungan anak membawa akibat hukum, baik dalam kaitannya dalam hukum tertulis maupun hukum tidak tertulis. Hukum merupakan jaminan bagi kegiatan perlindungan anak ((Gultom, 2014)).

Pasal 39 ayat (1) dan ayat (2) Peraturan Pemerintah Nomor 74 Tahun 2008 tentang Guru menyatakan:

"Guru memiliki kebebasan memberikan sanksi kepada peserta didiknya yang melanggar norma agama, norma kesusilaan, norma kesopanan, peraturan tertulis maupun tidak tertulis yang ditetapkan guru, peraturan tingkat satuan pendidikan, dan peraturan perundang-undangan dalam proses pembelajaran yang berada di bawah kewenangannya,"

Sanksi tersebut dapat berupa teguran dan/atau peringatan, baik lisan maupun tulisan, serta hukuman yang bersifat mendidik sesuai dengan kaedah pendidikan, kode etik guru, dan peraturan perundang-undangan.

Dalam hal mendidik, guru diberi perlindungan oleh hukum dalam menjalankan tugasnya sebagai pendidik, perlindungan tersebut termuat dalam 40 samapai Pasal 40 sampai 42 Paraturan Pemerintah Nomor 74 Tahun 2008 tentang Guru. Dalam Pasal 40 menyatakan bahwa:

Guru berhak mendapat perlindungan dalam melaksanakan tugas dalam bentuk rasa aman dan jaminan keselamatan dari Pemerintah, Pemerintah Daerah, satuan pendidikan, Organisasi Profesi Guru, dan/atau Masyarakat sesuai dengan kewenangan masing-masing Rasa aman dan jaminan keselamatan dalam melaksanakan tugas sebagaimana dimaksud pada ayat (1) diperoleh Guru melalui perlindungan: hukum; profesi; dan keselamatan dan kesehatan kerja. Masyarakat, Organisasi Profesi Guru, Pemerintah atau Pemerintah Daerah dapat saling membantu dalam memberikan perlindungan sebagaimana dimaksud pada ayat (1).

Pasal 41 menyatakan bahwa guru berhak mendapatkan perlindungan hukum dari tindak kekerasan, ancaman, perlakuan diskriminatif, intimidasi, atau perlakuan tidak adil dari pihak peserta didik, orang tua peserta didik, Masyarakat, birokrasi, atau pihak lain.

Guru berhak mendapatkan perlindungan profesi terhadap pemutusan hubungan kerja yang tidak sesuai dengan ketentuan peraturan perundangundangan, pemberian imbalan yang tidak wajar, pembatasan dalam menyampaikan pandangan, pelecehan terhadap profesi, dan pembatasan atau pelarangan lain yang dapat menghambat Guru dalam melaksanakan tugas.

Guru berhak mendapatkan perlindungan keselamatan dan kesehatan kerja dari satuan pendidikan dan penyelenggara satuan pendidikan terhadap resiko gangguan keamanan kerja, kecelakaan kerja, kebakaran pada waktu kerja, bencana alam, kesehatan lingkungan kerja dan/atau resiko lain.

Undang-undang dan Peraturan Pemerintah ini tampaknya menjadi sedikit berbenturan ketika guru dalam upayanya mendisiplinkan siswa harus berhadapan dengan Hukum Perlindungan Anak. Pasal 54 Undang-Undang Nomor 35 tahun 2014 tentang Perubahan Atas UndangUndang Nomor 23 Tahun 2002 Tentang Perlindungan Anak menyatakan: 
1) Anak di dalam dan di lingkungan satuan pendidikan wajib mendapatkan perlindungan dari tindak Kekerasan fisik, psikis, kejahatan seksual, dan kejahatan lainnya yang dilakukan oleh pendidik, tenaga kependidikan, sesama peserta didik, dan/atau pihak lain.

2) Perlindungan sebagaimana dimaksud pada ayat (1) dilakukan oleh pendidik, tenaga kependidikan, aparat pemerintah, dan/atau Masyarakat.

Pasal 76C Undang-Undang Nomor 35 tahun 2014 tentang Perubahan Atas UndangUndang Nomor 23 Tahun 2002 Tentang Perlindungan Anak menyatakan: "Setiap Orang dilarang menempatkan, membiarkan, melakukan, menyuruh melakukan, atau turut serta melakukan Kekerasan terhadap Anak"

Kemudian terdapat ketentuan Pasal 80 Undang-Undang Nomor 35 tahun 2014 tentang Perubahan Atas Undang-Undang Nomor 23 Tahun 2002 Tentang Perlindungan Anak yang menyatakan: "Setiap Orang dilarang menempatkan, membiarkan, melakukan, menyuruh melakukan, atau turut serta melakukan Kekerasan terhadap Anak"

Kemudian terdapat ketentuan Pasal 80 Undang-Undang Nomor 35 tahun 2014 tentang Perubahan Atas Undang-Undang Nomor 23 Tahun 2002 Tentang Perlindungan Anak yang menyatakan:

a) Setiap Orang yang melanggar ketentuan sebagaimana dimaksud dalam Pasal 76C, dipidana dengan pidana penjara paling lama 3 (tiga) tahun 6 (enam) bulan dan/atau denda paling banyak Rp72.000.000,00 (tujuh puluh dua juta rupiah).

b) Dalam hal Anak sebagaimana dimaksud pada ayat (1) luka berat, maka pelaku dipidana dengan pidana penjara paling lama 5 (lima) tahun dan/atau denda paling banyak Rp100.000.000,00 (seratus juta rupiah).

c) Dalam hal Anak sebagaimana dimaksud pada ayat (2) mati, maka pelaku dipidana dengan pidana penjara paling lama 15 (lima belas) tahun dan/atau denda paling banyak Rp3.000.000.000,00 (tiga miliar rupiah)

d) Pidana ditambah sepertiga dari ketentuan sebagaimana dimaksud pada ayat (1), ayat (2), dan ayat (3) apabila yang melakukan penganiayaan tersebut Orang Tuanya."

Pasal 80 ayat (1) merupakan pasal yang digunakan oleh orang tua murid melaporkan guru yang memberikan hukuman kepada muridnya. Seperti yang dialami seorang guru yang bernama Muhammad Samhudi. Muhammad Samhudi dituntut oleh Jaksa Penuntut Umum enam bulan penjara dengan masa percobaan satu tahun karena dinilai bersalah dan melanggar pasal 80 ayat (1) Undang-undang Perlindungan Anak. Undang-undang Perlindungan Guru dan Dosen adalah tesa, dan Undang-undang Perlindungan anak sebagai antitesa dalam konsep perlindungan bagi seorang Guru dalam menjalankan fungsi pendidikan, khususnya upaya penegakan disiplin siswa.

\section{Putusan Pengadilan sebuah Sintesa Perlindungan Hukum bagi Guru}

Kasus pertama yang diulas dalam penelitian ini adalah Putusan Mahkamah Agung Nomor 1554 K/PID/2013, dengan kronologi sebagai berikut:

Aop Saepudin seorang guru di SDN Panjalin Kidul 5 Sumber jaya majalengka dengan sengaja melakukan razia pemotongan rambut sebagai bagian dari tugas kesiswaan unttuk kelas 1 sampai dengan kelas 6 SD. Tugas tersebut sesuai dengan SK Nomor 423.5/01SD/2012 tanggal 09 Januari 2012. 
Berdasarkan SK tersebut, ia memiliki kewenangan melakukan Razia pemotongan rambut kepada siswa kelas 3 sampai kelas 6 yang berambut gondrong. Siswa yang terkena Razia anatara lain dilakukan kepada saksi Agus Nurcahya bin Toto, saksi Meiprik bin Imam Safei, saksi Muhamad Rizki bin Abdulah dan saksi Tomy Himawan Susanto bin Iwan Himawan.

Aop Saepudin memotong rambut siswa kelas 3 hanya sebelah kanan dekat daun telinga sedangkan yang lain pada rambut yang menyentuk daun telingan sebelah kiri, dan sebalah kanan, serta pada rambut bagian belakang bawah. Murid lainnya yaitu Muhammad Rizki menerima pemotongan rambut sebelah kanan diatas telinga kanan. Murid Tomi Himawan Susanto menerima potong rambut pada bagian kepala sebelah kiri diatas telinga, kemudian rambut sebelah kanan diatas telinga, rambut bagian belakang serta menarik rambut tersebut. Sedangkan murid yang lain yaitu Agus Larasakti memiliki rambut Panjang namun tidak dipotong. Tindakan Razia pemotongan rambut tersebut dilakukan tanpa pemberitahuan baik secara lisan maupun tertulis kepada orangtua siswa dan juga para murid, dan juga kepada Kepala Sekolah Panjalin Kidul V.

Akibat pemotongan rambut tersebut menimbulkan ketakutan bagi murid yang bernama Tomi Himawan Susanto yang merasa takut apabila melintasi ruang guru. Tindakan pemotongan rambut tersebut tidak diberitahukan kepada orangtua murid. Berdasarkan pemeriksaan psikologi Polda Jawa Barat disimpulkan bahwa murid mengalami trauma psikis dari peristiwa yang dialaminya. Hal tersebut mempengaruhi aktivitas belajar murid, pada akhirnya murid mengalami ketakutan, menghindari lingkungan dan bersikap pasif. Berdasarkan hal itu orangtua siswa Tomi Himawan Susanto segera melaporkan tindakan Aop Saepudin ke ranah hukum pidana.

Dalam Pertimbangan Putusan Mahkamah Agung, Hakim Agung menyatakan bahwa putusan Pengadilan Tinggi Bandung No. 226/PID/2013/- PT.BDG. tanggal 31 Juli 2013 yang menguatkan putusan Pengadilan Negeri Majalengka No. 257/Pid.B/2012/PN.Mjl. tanggal 2 Mei 2013 tidak dapat dipertahankan lagi, oleh karena itu harus dibatalkan, dan Mahkamah Agung akan mengadili sendiri perkara tersebut. Pertimbangan hakim Mahkamah Agung tersebut menjelaskan bahwa Putusan Pengadilan Tinggi Bandung No. 226/PID/2013/PT.BDG. yang telah menghukum terdakwa yaitu Aop Saepudin dibatalkan.

Hakim Mahkamah Agung tampaknya melihat bahwa Aop Saepudin tidak layak dipidana karena ia menjalankan tugas selaku pendidik. Ketika ia melakukan pemotongan rambut kepada siswa yaitu dalam hal ini juga terhadap pelapor yaitu Tomi Himawan Susanto, selaku siswa adalah dalam rangka menjalankan tugas dan fungsinya untuk mendisiplinkan siswa. Siswa dalam hal ini telah melanggar norma yang diterapkan oleh sekolah dimana ia belajar. Guru dalam menegakkan kedisiplinan bagi siswa dilindungi oleh peraturan perundangan.

Pasal 39 ayat (1) dan ayat (2) Peraturan Pemerintah Nomor 74 Tahun 2008 tentang Guru menyatakan:

"Guru memiliki kebebasan memberikan sanksi kepada peserta didiknya yang melanggar norma agama, norma kesusilaan, norma kesopanan, peraturan tertulis maupun tidak tertulis yang ditetapkan guru, peraturan tingkat satuan pendidikan, dan peraturan perundang-undangan dalam proses pembelajaran yang berada di bawah kewenangannya," 
Pasal 41 juga menyatakan bahwa:

Guru berhak mendapatkan perlindungan hukum dari tindak kekerasan, ancaman, perlakuan diskriminatif, intimidasi, atau perlakuan tidak adil dari pihak peserta didik, orang tua peserta didik, Masyarakat, birokrasi, atau pihak lain.

Pasal 39 dan 41 Peraturan Pemerintah No.74 Tahun 2008 secara tegas memberikan sebuah perlindungan bagi Guru. Ini adalah bentuk sintesa atas sebuah dialektika Guru menjalankan disiplin bagi muridnya. Guru dilindungi oleh seperangkat norma hukum dalam menjalankan fungsinya. Guru tidak layak mendapatkan hukuman ketika ia berupaya mendisiplinkan muridnya yang menjadi tanggungjawabnya. Teori Perlindungan Hukum yang diungkap oleh Satjipto Rahardjo mengungkapkan bahwa perlindungan hukum diberikan kepada masyarakat agar dapat menikmati semua hak-hak yang diberikan oleh hukum. Hukum dapat difungsikan untuk mewujudkan perlindungan yang sifatnya tidak sekedar adaptif dan fleksibel, melainkan juga prediktif dan antisipatif. Hukum dibutuhkan untuk mereka yang lemah dan belum kuat secara sosial, ekonomi dan politik untuk memperoleh keadilan sosial (Satjipto, 2006). Hukum melindungi guru yang lemah dalam menghadapi tekanan orang tua siswa yang seringkali lebih kuat secara ekonomi juga sosial.

Perlindungan bagi guru dalam mendidik, agar ia terlindungi haknya, untuk itu ia tidak dapat dipidana (Setiawan: 2017). Bentuk kekerasan terhadap guru yang dilakukan oleh siswa atau orangtunya menjadi bentuk dari sebuah pergeseran moral yang semakin menurun dalam masyarakat (Nurmala, 2018). Guru wajib mendapatkan perlindungan hukum dari segala anomaly yang berpotensi menimpa para guru, baik yang dilakukan oleh siswa orangtua siswa, juga termasuk dari apparat birokrasi (Komara, 2016). Perlu difahami lebih mendalam bahwasanya guru dalam menjalankan profesinya termasuk dalam hal ini mendisiplinkan siswa adalah dalam upaya menciptakan tujuan negara yaitu mencerdaskan kehidupan bangsa sesuai amanah Konstitusi (Dewanto, n.d.). Dalam hal mewujudkan citacita bangsa yang luhur tersebut tugas guru menjadi sangat berat karena ia memiliki tugas mulia mencapai sebuah cita-cita bangsa (Harun, 2016).

\section{CONCLUSION}

Dari pembahasan tersebut di atas dapat dilihat kesimpulan sebagai berikut:

1. Pertama, bahwa Guru acapkali mengalami kegamangan dalam menjalankan tugasnya. Ia seringkali mengalami ketakutan akan adanya ancaman pidana dari orangtua siswa, akibat upaya pendisiplinan guru terhadap murid. Dalam konteks dialektika antar norma yang saling bertemu, tampak sebuah sintesa hukum melalui hadirnya Putusan Mahkamah Agung yang mampu memberikan perlindungan bagi guru.

2. Kedua, bahwa Putusan Mahkamah Agung No. 1554 K/PID/2013 telah mampu memberikan perlindungan secara optimal bagi guru untuk menjalankan fungsinya selaku pendidik. Guru menjalankan tugas dan fungsinya selaku pendidik tidak dapat dihukum oleh sebuah tekanan apapun. Ia menjalankan sebuah fungsi-fungsi pendidikan sebagai soko guru bangsa yang beradab. Tindakan guru tetaplah selalu harus berada dalam koridor hukum, dan tidaklah berbentuk penyiksaan fisik terhadap siswanya.

\section{REFERENCES}

Amri, S. (2013). Pengembangan dan model pembelajaran dalam kurikulum 2013. Jakarta:

Prestasi Pustaka. 
Aulina, C. N. (2013). Penanaman disiplin pada anak usia dini. PEDAGOGIA: Jurnal Pendidikan, 2(1), 36-49.

Citra, Y. (2012). Pelaksanaan Pendidikan Karakter dalam Pembelajaran. Jurnal Ilmiah Pendidikan Khusus, 1(1), 237-249.

Dewanto, S. A. (n.d.). Perlindungan Guru di Era Reformasi. 8.

Diantha, I. M. P. (2016). Metodologi penelitian hukum normatif dalam justifikasi teori hukum. Prenada Media.

Fachrian, M. R. (2020). Perlindungan Hukum Bagi Guru Terhadap Tindakan Siswayang Menghina Guru Di Ruang Kelas.

Gandara, A. (2018). Pemberian sanksi oleh guru terhadap siswa yang melanggar peraturan sekolah dihubungkan dengan Undang-undang nomor 17 tahun 2016 tentang perlindungan anak Juncto peraturan pemerintah nomor 19 tahun 2017 tentang guru [PhD Thesis]. UIN Sunan Gunung Djati Bandung.

Gultom, M. (2014). Perlindungan hukum terhadap anak dalam sistem peradilan pidana anak di Indonesia. Refika Aditama.

Haikal, M. (2017). Tinjauan Yuridis Tentang Perlindungan Hukum Bagi Guru Terkait Tindakan Pemberian Hukuman (Punishment) Terhadap Upaya Mendisiplinkan Siswanya [PhD Thesis]. Universitas Negeri Semarang.

Hanafy, M. S. (2014). Konsep Belajar dan Pembelajaran. Lentera Pendidikan: Jurnal Ilmu Tarbiyah Dan Keguruan, 17(1), 66-79.

Harun, H. (2016). Perlindungan Hukum Profesi Guru dalam Perspektif Hukum Positif. Law and Justice, 1(1), 74-84.

Hurlock, E. B. (2001). Developmental psychology. Tata McGraw-Hill Education.

Imron, A. (2011). Manajemen peserta didik berbasis sekolah. Jakarta: Bumi Aksara.

Komara, E. (2016). Perlindungan Profesi Guru di Indonesia. Mimbar Pendidikan, 1(2).

Matnuh, H. (2017). Perlindungan Hukum profesionalisme Guru. Jurnal Pendidikan Kewarganegaraan, 7(2), 46-50.

Muchith, M. S. (2016). Radikalisme dalam dunia pendidikan. Addin, 10(1), 163-180.

Mukti Fajar, N. D., \& Achmad, Y. (2010). Dualisme Penelitian Hukum: Normatif \& Empiris. Pustaka Pelajar.

Mulyani, E. (2011). Model pendidikan kewirausahaan di pendidikan dasar dan menengah. Jurnal Ekonomi Dan Pendidikan, 8(1).

Nurmala, L. D. (2018). Perlindungan Hukum Terhadap Tenaga Pendidik. Gorontalo Law Review, 1(1), 67-76. 
Panjaitan, T. R. A., \& Mahzaniar, H. H. (2019). Tinjaun Yuridis Tentang Perlindungan Hukum Bagi Guru Terkait Tindakan Pemberian Hukuman (Punisment) Terhadap Upaya Mendisiplinkan Siswanya (Studi Kasus SD 117513 Pulo Tarutung). PROSIDING SEMINAR NASIONAL HASIL PENELITIAN, 2(2), 1404-1408.

Satjipto, R. (2006). Ilmu Hukum. Bandung, PT. Citra Aditya Bakti.

Sinungan, M. (2018). Produktivitas apa dan Bagaimana. Bumi Aksara.

Soekanto, S., \& Mamudji, S. (2001). Penelitian hukum normatif: Suatu tinjauan singkat. RajaGrafindo Persada.

Sudibyo, A., \& Kiyamudin, E. (2019). Perlindungan Hukum Terhadap Guru Dalam Melaksanakan Tugas Keprofesionalannya Dikaitkan Dengan Punishment Dalam Mendisiplinkan Siswa. Journal Presumption of Law, 1(2).

Suprihatin, S. (2015). Upaya guru dalam meningkatkan motivasi belajar siswa. Jurnal Pendidikan Ekonomi UM Metro, 3(1), 73-82.

Susanti, R. (2011). Membangun pendidikan karakter di sekolah melalui kearifan lokal. Diakses Dari: Http://Eprints. Unsri. Ac. Id/26/3/Makalah_Seminar_Kearifan_Lokal. Pdf. Sutisna, O. (1983). Administrasi Pendidikan: Dasar Teoritis untuk Praktek Profesional. Angkasa, Bandung.

Tampubolon, S. M. (2013). Mengembangkan Kecerdasan Spiritual Mahasiswa di Perguruan Tinggi. Humaniora, 4(2), 1203-1211. 